\title{
Suppressor of cytokine signaling 1 gene mutation status as a prognostic biomarker in classical Hodgkin lymphoma
}

\author{
Jochen K. Lennerz ${ }^{1,2, *}$, Karl Hoffmann ${ }^{1,3, *}$, Anna-Maria Bubolz ${ }^{1}$, Davor Lessel ${ }^{4,5}$, \\ Claudia Welke ${ }^{6}$, Nele Rüther ${ }^{1}$, Andreas Viardot ${ }^{7}$, Peter Möller ${ }^{1}$ \\ ${ }^{1}$ UIm University, Institute of Pathology, Ulm, Germany \\ ${ }^{2}$ Massachusetts General Hospital/Harvard Medical School, Department of Pathology, Center for Integrated Diagnostics, \\ Boston, MA, USA \\ ${ }^{3}$ Department of Dermatology and Venerology, University of Freiburg Medical Center, Freiburg, Germany \\ ${ }^{4}$ UIm University, Institute of Human Genetics, Ulm, Germany \\ ${ }^{5}$ University Medical Center Hamburg-Eppendorf, Institute of Human Genetics, Hamburg, Germany \\ ${ }^{6}$ Comprehensive Cancer Center, UIm University, UIm, Germany \\ ${ }^{7}$ UIm University, Department of Internal Medicine III, UIm, Germany \\ *These authors have contributed equally to this work
}

Correspondence to:

Jochen K. Lennerz, e-mail: JLennerz@partners.org

Keywords: SOCS1, Hodgkin lymphoma, CHL, prognostic biomarker

Received: April 02, $2015 \quad$ Accepted: August 07, $2015 \quad$ Published: August 20, 2015

\section{ABSTRACT}

Suppressor of cytokine signaling 1 (SOCS1) mutations are among the most frequent somatic mutations in classical Hodgkin lymphoma (cHL), yet their prognostic relevance in $\mathrm{cHL}$ is unexplored. Here, we performed laser-capture microdissection of Hodgkin/Reed-Sternberg (HRS) cells from tumor samples in a cohort of 105 cHL patients. Full-length SOCS1 gene sequencing showed mutations in $61 \%$ of all cases $(n=64 / 105)$. Affected DNA-motifs and mutation pattern suggest that many of these SOCS1 mutations are the result of aberrant somatic hypermutation and we confirmed expression of mutant alleles at the RNA level. Contingency analysis showed no significant differences of patient-characteristics with HRS-cells containing mutant vs. wild-type SOCS1. By predicted mutational consequence, mutations can be separated into those with non-truncating point mutations ('minor' $n=49 / 64=77 \%$ ) and those with length alteration ('major'; $n=15 / 64=23 \%$ ). Subgroups did not differ in clinicopathological characteristics; however, patients with HRS-cells that contained SOCS1 major mutations suffered from early relapse and significantly shorter overall survival $(P=0.03)$. The SOCS1 major status retained prognostic significance in uni- $(P$ $=0.016)$ and multivariate analyses $(P=0.005)$. Together, our data indicate that the SOCS1 mutation type qualifies as a single-gene prognostic biomarker in $\mathrm{cHL}$.

\section{INTRODUCTION}

The majority of patients with classical Hodgkin lymphoma will achieve complete remission with current treatment strategies [1]. Stage-appropriate treatment approaches include the combination of a short course of chemotherapy and involved field radiation in early stage disease $[2,3]$ whereas the approach in advanced disease is a prolonged course of chemotherapy followed by positron emission tomography (PET)-guided radiotherapy [4]. The overall impressive therapy outcomes are overshadowed by subsets of patients with high-risk advanced disease (e.g. post-treatment PET positive) [4], those patients not fit for intensive treatment regimen [5] as well as elderly patients [6]. Relapsed Hodgkin lymphoma remains curable in those patients who are suitable for high-dose chemotherapy and autologous stem cell treatment [7]. Emerging new treatments, including antibody-drug conjugate brentuximab-vedotin [8] or the immunologic checkpoint inhibitors nivolumab [9] promise further substantial improvements in relapsed patients and also in first line patients in future. 
All these successes are beclouded by long-term toxicities including secondary neoplasms [10], cardiac failure [11], and/or infertility [12]. In the last decade, a sizeable number of clinical trials focused on reduction of toxicity and lead to further improvement while maintaining excellent outcomes. Collectively, only posttreatment PET was established as a marker for response without additional radiotherapy in advanced Hodgkin lymphoma [4]. However, there is no reliable routinediagnostic biomarker enabling upfront identification of cHL patients that do not show response to therapy $[13,14]$. One reason may be related to the specific pathobiology of cHL with the neoplastic cells, the Hodgkin Reed-Sternberg cells (HRS), composing only a small part of the cellular tumor mass [15]. Consequently, several studies in the last decade have focused on the surrounding inflammatory infiltrate albeit with variable results - especially regarding prognostication [16]. Similarly, the high inter-rater variability and subjective nature of immunohistochemical (i.e., tissue-based HRS-cell) biomarkers precluded establishing reliable tissue-based prognostic markers [17] (NCT01505712; http://www.clinicaltrials.gov).

Suppressor of cytokine signaling 1 (SOCS1) mutations have been described in specific sets of malignant lymphomas [18]. For example $35 \%$ of primary mediastinal B-cell lymphomas [19] and 16\% of diffuse large B-cell lymphomas harbor SOCS1 mutations [20]. In cHL cases, we have previously described SOCS1 mutations in $45-52 \%$ [21]. The encoded SOCS1 protein inhibits janus kinase and signal transducer and activator of transcription (JAK/ STAT) signaling, and the C-terminal domain including the SOCS box is necessary for this function [22, 23]. We have shown that mutations affecting this domain result in abnormal stabilization of JAK2 and dysregulation of JAK/ STAT signaling [24]. While the specific pathobiological role in lymphomagenesis remains to be elucidated, SOCS1 is a postulated tumor suppressor gene, that is frequently targeted by somatic hypermutation $[18,20,25,26]$ and inactivated by genomic mutations $[21,22,24]$. We have recently reported that the SOCS1 mutation status in DLBCL carries prognostic significance [20]; however, despite being one of the most frequent recurrent somatic mutation in $\mathrm{cHL}$, the clinical relevance of SOCS1 mutations has not been examined.

The aim of the present study was to determine the clinical phenotype and prognostic significance of the SOCS1 mutation status in a cohort of cHL patients. We found that SOCS1 mutations occur in more than $60 \%$ of $\mathrm{cHL}$ patients and that mutational subtypes have different prognostic implications. Thus, the SOCS1 mutation status in HRS cells represents a novel, tumor cell-derived, single gene prognostic biomarker in cHL.

\section{RESULTS}

Our study cohort is composed of 105 histologically confirmed cases of cHL. Specifically, 100 cases were chosen as consecutively cryobanked samples. To increase statistical power, we followed a previous approach [27] and attempted to genotype 12 relapsed patients by establishing a separate 5-fragment PCR for SOCS1 sequencing from FFPE samples (Supplementary Figure S1; Supplementary Table S1). Due to insufficient DNA-quality, we ultimately added 5 of the 12 patients with treatment failure. An overview of the study cohort is provided in Table 1 and based on the clinical characteristics we consider our cohort representative of $\mathrm{cHL}$.

\section{Table 1: Characteristics of patients with classical Hodgkin lymphoma in the study cohort}

\begin{tabular}{|c|c|c|}
\hline & Patients $(N=105)$ & \\
\hline Characteristic & No. & $\%$ \\
\hline \multicolumn{3}{|l|}{ Demographics } \\
\hline Age, median (range) & \multicolumn{2}{|c|}{$28.2(7-81)$} \\
\hline Female & $59 / 105$ & 56 \\
\hline Male & $46 / 105$ & 44 \\
\hline \multicolumn{3}{|l|}{ Morphology } \\
\hline Nodular sclerosing & $66 / 105$ & 63 \\
\hline Lymphocyte rich & $18 / 105$ & 17 \\
\hline Mixed cellularity & $16 / 105$ & 15 \\
\hline Lymphocyte depleted & $2 / 105$ & 2 \\
\hline NOS & $3 / 105$ & 3 \\
\hline \multicolumn{3}{|l|}{ Ann-Arbor Stage } \\
\hline Stage I & $5 / 101$ & 5 \\
\hline Stage II & $51 / 101$ & 50 \\
\hline
\end{tabular}

(Continued) 


\section{Patients $(N=105)$}

\begin{tabular}{|c|c|c|}
\hline Characteristic & No. & $\%$ \\
\hline Stage III & $23 / 101$ & 23 \\
\hline Stage IV & $22 / 101$ & 22 \\
\hline \multicolumn{3}{|l|}{ Clinical Parameter } \\
\hline$<3$ LN-Areas & $33 / 101$ & 33.3 \\
\hline Age $\geq 45$ & $17 / 105$ & 16 \\
\hline B-Symptoms & $47 / 96$ & 49 \\
\hline EN-sites $N=0$ & $77 / 101$ & 76.2 \\
\hline EN-sites $N=1$ & $16 / 101$ & 15.8 \\
\hline EN-sites $N \geq 2$ & $8 / 101$ & 8 \\
\hline Spleen involved & $10 / 101$ & 10 \\
\hline Mediastinum & $77 / 101$ & 76 \\
\hline Inguinal LN & $4 / 101$ & 4 \\
\hline \multicolumn{3}{|l|}{ Laboratory Parameters } \\
\hline EBV-positive & $13 / 76$ & 17 \\
\hline Elevated LDH $>250 \mathrm{U} / 1$ & $16 / 95$ & 16.8 \\
\hline Leukocytosis $\geq 15000 / \mu 1$ & $25 / 99$ & 25 \\
\hline Hypoalbuminemia $<4 \mathrm{~g} / \mathrm{dl}$ & $33 / 75$ & 44 \\
\hline $\mathrm{Hb} .<10.5 \mathrm{~g} / \mathrm{dl}$ & $21 / 98$ & 21 \\
\hline Incr. sed.-rate $>50 \mathrm{~mm} / \mathrm{h}$ & $39 / 70$ & 56 \\
\hline \multicolumn{3}{|l|}{ Therapy } \\
\hline ABVD & $39 / 101$ & 38.6 \\
\hline BEACOPP & $44 / 101$ & 43.6 \\
\hline Other & $18 / 101$ & 17.8 \\
\hline Radiation (yes) & $68 / 99$ & 69 \\
\hline Radiation (no) & $31 / 99$ & 31 \\
\hline
\end{tabular}

Abbreviations: EN, extranodal; EBV, Epstein-Barr Virus; ESR, erythrocyte sedimentation rate; LDH, lactate dehydrogenase $>250 \mu \mathrm{g}$; Hb, hemoglobin; N, number of cases per genotype-specific subgroup; No., number of patients; LN, lymph node.

\section{Somatic SOCS1 mutations occur in $\sim 60 \%$ of $\mathrm{cHL}$ patients}

We laser-capture microdissected $>50-1000 \mathrm{HRS}$ cells per patient sample (Figure 1a) and performed fulllength sequencing of the SOCS1 gene. We identified SOCS1 mutations in HRS cells from 64 of 105 patients (61\%). In 30 cases, we also laser-capture microdissected $>100-500$ cells of the surrounding cells ('infiltrate'); however, failed to detect SOCS1 mutations. In conjunction, these data confirm that in cHL, SOCS1 mutations are HRS-cell specific and the prevalence of $61 \%$ makes SOCS1 mutations to one of the most frequent recurrent somatic mutational event in $\mathrm{cHL}$. Figure $1 \mathrm{~b}$ summarizes all mutations within the coding region of SOCS1 (see also Supplementary Table S2).

\section{SOCS1 mutations differ by length of intact coding sequence}

In total, we found 140 unique mutational events in 64 separate cases (referred to as SOCS1 mutant). In most mutant cases $(\sim 85.9 \%)$ the mutation was admixed with wild-type sequence (heterozygous pattern) whereas 9 of the 64 SOCS1 mutant cases (14.1\%) showed a homozygous mutation pattern (either due to loss of the wild-type allele or a biallelic mutation). Twenty-six of the 64 SOCS1 mutant cases carried single point mutations $(40.6 \%)$, whereas multiple mutations accumulated in 38 cases (59.4\%; Figure 1b). Mapping of the SOCS1 mutations over the coding region showed a pattern similar to that observed in other tumor suppressor genes. In comparison to the distribution of 


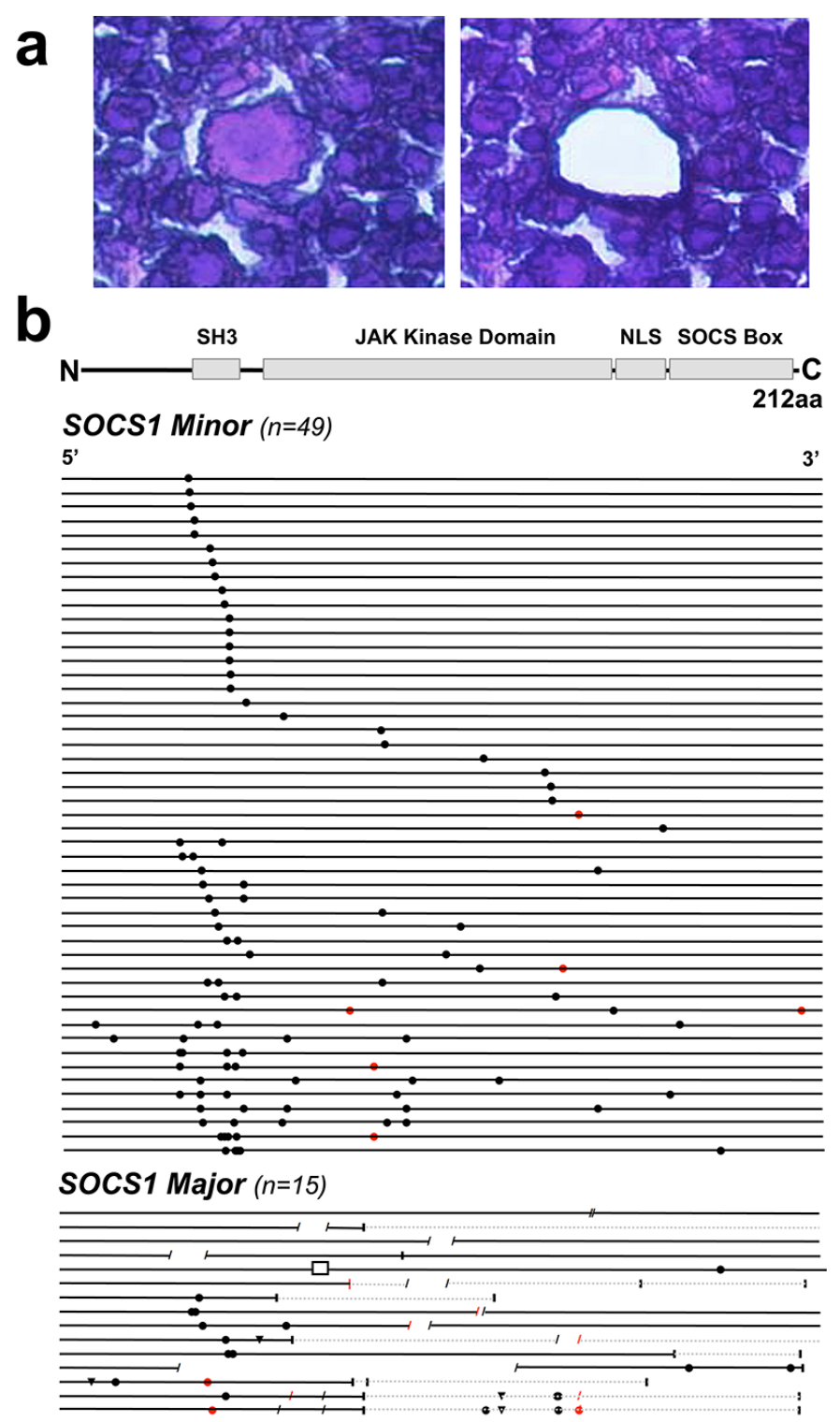

C


Figure 1: SOCS1 Mutations in Microdissected Hodgkin/Reed-Sternberg (HRS) cells in classical Hodgkin Lymphoma (cHL). a. The histological composition of cHL necessitates laser capture microdissection for accurate genotyping of the neoplastic HRS-cells (center; before and after laser capture microdissection) vs. surrounding inflammatory cells. b. Mutational analysis of the SOCS1 gene in laser-capture microdissected HRS cells from patients with cHL. The coding region (length: $636 \mathrm{bp}$ ) is shown as a black line and symbols visualize the type and site of each mutation. Mutations that do not alter the length of the encoded protein are grouped as 'minor' mutations whereas those HRS that harbor indels and/or truncating mutations were grouped as 'major'. Circles are replacement substitutions, triangles are single nucleotide deletions, diagonal lines are deletions of more than one nucleotide, a box represents an insertion, and vertical lines symbolize premature stop codons followed by grey lines that represent non-sense sequence. Symbols are red when mutations occurred at sites with a consensus motif for somatic hypermutation (see methods). Abbreviations: SH3, Src homology 3; JAK, Janus kinase; NLS, nuclear localization signal; SOCS box, silencer of cytokine signaling box. c. Distribution of somatic mutations from the transcription initiation site. Mutation frequency indicates the number of mutation per overlapping intervals of $100 \mathrm{bp}$ in the mutated $\mathrm{cHL}$ and is plotted aginast the distance $(\mathrm{kb})$ from the transcription initiation site (arrow in scheme of genomic locus). 
SOCS1 mutations in other lymphomas [18, 20, 26], point mutations in cHL showed a higher prevalence in the SH3 domain, whereas deletions predominantly affected the JAK Kinase Domain (Figure 1b, Supplementary Table S2). By mutation-type we found 18 deletions, 1 insertion and 121 point mutations (single-nucleotide substitutions). The singlenucleotide substitutions were composed of 19 synonymousand the 102 non-synonymous point mutations consisted of 99 missense and 3 non-sense mutations. We also screened for single nucleotide polymorphisms (at positions c.58, 381, $384,421,558,577,593,595,597,630)$; however, found the wild-type allele in all microdissected HRS- and all 30 inflammatory infiltrate samples. SOCS1 mutations rarely localize primarily to C-terminal domains; however, when consequences of upstream mutations were considered [20], the fraction of cases with predicted alterations in C-terminal domains increased substantially. The deleterious impact of truncations and/or frameshifts that alter longer stretches of the gene, affected in particular the SOCS box (range $51-100 \%$ of SOCS1 mutant cHL). Thus, SOCS1 C-terminal domains including the terminal part of the JAK-domain, the nuclear localization sequence (NLS) and the entire SOCS box (Figure 1b) are rarely affected by primary mutational events; however, these $\mathrm{C}$-terminal domains are mutated or lost due to more severe proximal mutations [20]. Consequently, SOCS1 sequence analysis implies different degrees of mutational severity, which can be visualized via the length of intact coding sequence (Figure 1b). Accordingly, we followed prior designations [20] and defined SOCS1 minor as cases that harbor only non-foreshortening point mutations (49 of 64 SOCS1 1 mutated cases in our $\mathrm{cHL}$ cohort $=76.6 \%$ ), and the SOCS1 major group as cases with at least one lengthalternating mutational event (15 of 64 SOCS1 mutated cases in our cHL cohort $=23.4 \%$ ). To account for these differences, we performed subgroup analyses based on the two mutation subtypes (SOCS1 minor vs. major).

\section{SOCS1 mutations occur at somatic hypermutation (SHM) motifs}

Prior studies have suggested that SOCS1 mutations might be the result of SHM [18, 20, 25, 26]. When taking the untranslated exon 1 (101 bp), intron 1-2 $(550 \mathrm{bp})$, and the untranslated region of exon $2(50 \mathrm{bp})$ into account, the highest frequency of point mutations localizes to $\sim 0.5-0.8 \mathrm{~kb}$ from the transcription initiation site (Figure 1C). These findings are in line with the frequency distributions found in other genes targeted by SHM [28] and may explain the relative high frequency of point mutations in the $\mathrm{SH} 3$ domain. Additionally, we checked the hotspot consensus motifs (RGYW/WRCY, DGYW/WRCH and WA/TW) [29-31] known as somatic hypermutation target sites that result in single nucleotide substitutions (Supplementary Table S2). We found 16 mutations occurring in these SHM motifs and notably $69 \%$ matched the RGYW motif [30], which is in line with the high prevalence of G/C substitutions ( $96 \%$ vs. only $n$ $=5 \mathrm{~A} / \mathrm{T}$ substitutions) in SHM [28]. Furthermore, in five cases at least one flanking site of a deletion matched one of the SHM consensus motifs, and in one of the major cases (total of 6 mutations), position c. 429 was affected on both alleles (one by a missense mutation, the other by a deletion; Supplementary Table S2). Although comparison to mutational rates at SHM consensus motifs in $\mathrm{cHL}(n=$ $16 / 166=9 \%$ ) is significantly lower than that observed in DLBCL $(n=33 / 120 ; 27.5 \% ; P<0.01$, Fisher's exact test) [20], our data suggest that SOCS1 mutations are at least in part caused by aberrant SHM.

\section{Expression of mutant SOCS1 alleles in HRS cells in primary $\mathrm{cHL}$ samples}

Some of the detected mutations in the coding region are predicted deleterious and likely inactivate the tumor suppressor SOCS1. However, as most HRS cells carry, in addition to a mutant, a wild-type allele (Figure 2, top traces DNA from HRS-cells) it is not clear if the mutant SOCS1 gene is expressed. Therefore, we isolated RNA from microdissected HRS cells in 28 cases. In 14 cases yields were too low/insufficient; however, genotyping revealed expression of mutated alleles in 6 of 11 SOCS1 minor- and in 2 of 3 SOCS1 major cases. Representative examples of two SOCS1 minor and one SOCS1 major case are provided in (Figure 2). Specifically, one of the SOCS1 minor cases demonstrated loss of heterozygosity for the mutated base at position c.115 (Figure 2, middle) and genotyping of the corresponding RNA demonstrated expression of the mutated allele. Thus, we show that not

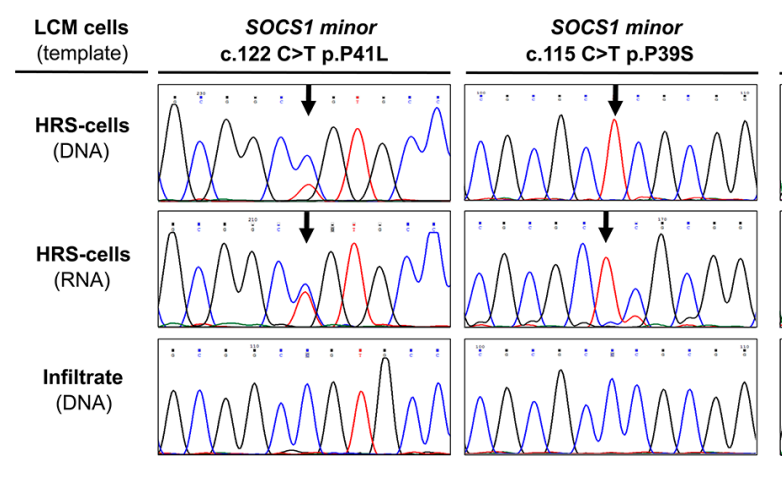

www.impactjournals.com/oncotarget

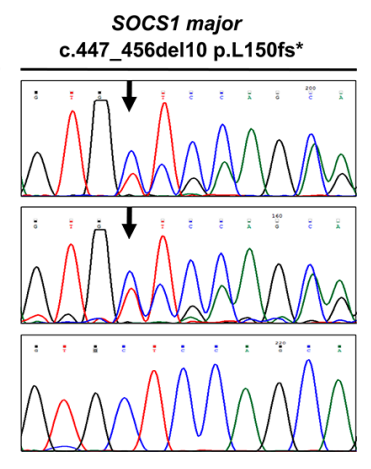

Figure 2: Expression of SOCS1 Mutations in Hodgkin/Reed-Sternberg(HRS cells in classical Hodgkin Lymphoma (cHL). Sanger sequencing of nucleic acids, isolated from laser capture microdissected (LCM) cellular subsets demonstrates presence and expression of the mutant allele in HRS cells. Note: the major mutation shown here was detected in a sample genotyped at time of progression; this major mutation was not present in the primary biopsy and is therefore not included in the analysis or Figure 1. 
only cHL cell lines [21], but also SOCS1 mutated HRS cells in lymphoma tissue express the mutant allele.

\section{Clinical phenotype and follow-up in SOCS1 mutated cHL}

Contingency analysis of epidemiological, clinicopathological, and therapeutic characteristics in our cHL cohort with respect to their co-occurrence with SOCS1 mutations, or mutation subtypes, showed no significant differences or associations (Table 2). Specifically, phenotype analysis delineated that no specific characteristic allows discrimination of either the SOCS1 wildtype, mutant, minor, or major subgroup. Therefore, the SOCS1 mutation status or subtype cannot be inferred from a basic panel of parameters. Importantly, the applied treatment regimens showed no significant differences when compared between mutational subtypes (Table 1,2). At the time of data evaluation, we separated outcome by freedom from disease progression (FFDP) and overall survival (OS) (Figure 3). The median follow-up time for FFDP was 5.2 years (range: 1 month - 14 years) with $19 \%$ of patients suffering from relapse or refractory disease $(N=20 / 105$; Figure $3 a)$. The median follow-up time for OS was 6.6 years (range: 1 month - 17 years). Fourteen patients $(\sim 13 \%)$ had died of disease and 91 of 105 patients ( $\sim 87 \%)$ were censored (either alive or lost to follow-up; Figure $3 b$ ). These outcome characteristics are comparable with previously reported outcomes $[32,33]$ and we, thus, consider our cohort representative for the study of prognostic biomarkers in cHL.

\section{Outcome differs by mutational subtype}

Outcome analysis comparing patients with HRS-cells harboring mutant vs. wild-type SOCS1 showed no significant differences with respect to FFDP $(P=0.77$; Figure $3 \mathrm{c})$; however, we found a trend towards shorter overall survival in the SOCS1 mutant subgroup ( $P=0.36$; Figure $3 \mathrm{~d})$; which was exaggerated when restricting statistical comparison to the initial 5 years $(P=0.18$; Figure $3 \mathrm{~d})$. Comparison by mutation subtype showed that cHL patients with HRS-cells that harbor SOCS1 minor mutations had different time courses of FFDP when compared to the SOCS1 major subgroup $(P=0.05$; Figure 3e); however, overall survival of SOCS1 minor patients was similar to SOCS1 wild-type patients $(P=0.88$; Figure $3 \mathrm{f})$. In contrast, patients with HRScells that harbored SOCS1 major mutations suffered from a higher fraction of earlier relapse (Figure 3e; $P=0.05)$ and significantly shorter overall survival when compared to SOCS1 wild-type $(P=0.016$; Figure $3 \mathrm{f})$ or SOCS1 minor patients $(P=0.03$; Figure $3 \mathrm{f})$. We corroborated these observations in univariate comparisons of the SOCS1 mutation status (major, minor, both) with 13 other covariates revealed that the SOCS1 major status is associated with distinct prognostic fates. While FFDP

Table 2: Characteristics of SOCS1 genotype-specific subsets of patients with classical Hodgkin Lymphoma

\begin{tabular}{cccccccc} 
SOCS1-wild- & $\begin{array}{c}\text { SOCS1- } \\
\text { mutated } \\
N=64\end{array}$ & $\begin{array}{c}\text { SOCS1-minor } N=41 \\
N=49\end{array}$ & $\begin{array}{c}\text { SOCS1-major } \\
N=15\end{array}$ & $P$ & $P$ & $P$ & $P$ \\
& & & & & \\
\hline
\end{tabular}

\begin{tabular}{|c|c|c|c|c|c|c|c|c|c|c|c|c|}
\hline Characteristic & No. & $\%$ & No. & $\%$ & No. & $\%$ & No. & $\%$ & $\begin{array}{c}\text { WT } \\
\text { vs. } \\
\text { mut. }\end{array}$ & $\begin{array}{c}\text { WT } \\
\text { vs. } \\
\text { Minor }\end{array}$ & $\begin{array}{c}\text { WT } \\
\text { vs. } \\
\text { Major }\end{array}$ & $\begin{array}{l}\text { Major } \\
\text { vs. } \\
\text { Minor }\end{array}$ \\
\hline
\end{tabular}

\begin{tabular}{|l|c|c|c|c|c|c|c|c|c|c|c|c|c|}
\hline Demographics & & & & & & & & & & & & \\
\hline $\begin{array}{c}\text { Age, median } \\
\text { (range) }\end{array}$ & \multicolumn{2}{|c|}{$25.1(7-73)$} & \multicolumn{2}{|c|}{$29.22(11-81)$} & $30.2(11-76)$ & $28.9(13-81)$ & $0.26^{\mathrm{t}}$ & $0.25^{\mathrm{t}}$ & $0.52^{\mathrm{t}}$ & $0.9^{\mathrm{t}}$ \\
\hline Female & $23 / 41$ & 56 & $36 / 64$ & 56 & $27 / 49$ & 55 & $9 / 15$ & 60 & 1.0 & 1.0 & 1.0 & 0.76 \\
\hline Morphology & & & & & & & & & $0.7^{\mathrm{c}}$ & $0.57^{\mathrm{c}}$ & $0.79^{\mathrm{c}}$ & $0.52^{\mathrm{c}}$ \\
\hline Nodular sclerosing & $29 / 41$ & 70.7 & $37 / 64$ & 57.8 & $27 / 49$ & 55.1 & $10 / 15$ & 66.6 & 0.22 & 0.19 & 0.76 & 0.55 \\
\hline Lymphocyte rich & $5 / 41$ & 12.2 & $13 / 64$ & 20.3 & $12 / 49$ & 24.5 & $1 / 15$ & 6.7 & 0.43 & 0.18 & 1.0 & 0.27 \\
\hline Mixed cellularity & $5 / 41$ & 12.2 & $11 / 64$ & 17.2 & $8 / 49$ & 16.3 & $3 / 15$ & 20 & 0.58 & 0.77 & 0.67 & 0.71 \\
\hline $\begin{array}{c}\text { Lymphocyte } \\
\text { depleted }\end{array}$ & $1 / 41$ & 2.4 & $1 / 64$ & 1.6 & $1 / 49$ & 2 & $0 / 15$ & 0 & 1.0 & 1.0 & 1.0 & 1.0 \\
\hline NOS & $1 / 41$ & 2.4 & $2 / 64$ & 3.1 & $1 / 49$ & 2 & $1 / 15$ & 6.7 & 1.0 & 1.0 & 0.47 & 0.42 \\
\hline Ann-Arbor Stage & & & & & & & & & $0.12^{\mathrm{c}}$ & $0.11^{\mathrm{c}}$ & $0.44^{\mathrm{c}}$ & $0.77^{\mathrm{c}}$ \\
\hline \begin{tabular}{c} 
Stage I \\
\hline
\end{tabular} & $1 / 39$ & 2.6 & $4 / 62$ & 6.5 & $4 / 49$ & 8.2 & $0 / 13$ & 0 & 0.65 & 0.38 & 1.0 & 0.58 \\
\hline
\end{tabular}

(Continued) 


\begin{tabular}{|c|c|c|c|c|c|c|c|c|c|c|c|c|}
\hline \multirow[b]{2}{*}{ Characteristic } & \multicolumn{2}{|c|}{$\begin{array}{c}\text { SOCS1-wild- } \\
\text { type } N=41\end{array}$} & \multicolumn{2}{|c|}{$\begin{array}{c}\text { SOCS1- } \\
\text { mutated } \\
N=64\end{array}$} & \multicolumn{2}{|c|}{$\begin{array}{c}\text { SOCS1-minor } \\
N=49\end{array}$} & \multicolumn{2}{|c|}{$\begin{array}{c}\text { SOCS1-major } \\
N=15\end{array}$} & \multirow{2}{*}{$\begin{array}{c}P \\
\\
\text { WT } \\
\text { vs. } \\
\text { mut. } \\
\end{array}$} & \multirow{2}{*}{$\begin{array}{c}P \\
\\
\text { WT } \\
\text { vs. } \\
\text { Minor }\end{array}$} & \multirow{2}{*}{$\begin{array}{c}P \\
\\
\text { WT } \\
\text { vs. } \\
\text { Major }\end{array}$} & \multirow{2}{*}{$\begin{array}{c}P \\
\\
\text { Major } \\
\text { Vs. } \\
\text { Minor }\end{array}$} \\
\hline & No. & $\%$ & No. & $\%$ & No. & $\%$ & No. & $\%$ & & & & \\
\hline Stage II & $25 / 39$ & 64 & $26 / 62$ & 41.9 & $20 / 49$ & 40.8 & $6 / 13$ & 46.2 & 0.04 & 0.36 & 0.33 & 1.0 \\
\hline Stage III & $5 / 39$ & 12.8 & $18 / 62$ & 29 & $14 / 49$ & 28.6 & $4 / 13$ & 30.8 & 0.08 & 0.12 & 0.2 & 1.0 \\
\hline Stage IV & $8 / 39$ & 20.5 & $14 / 62$ & 22.6 & $11 / 49$ & 22.4 & $3 / 13$ & 23 & 1.0 & 1.0 & 1.0 & 1.0 \\
\hline \multicolumn{13}{|l|}{ Clinical Parameter } \\
\hline$<3$ LN-Areas & $10 / 39$ & 25.6 & $23 / 62$ & 37.1 & $16 / 49$ & 32.7 & $7 / 13$ & 53.8 & 0.28 & 0.49 & 0.09 & 0.52 \\
\hline Age $\geq 45$ & $5 / 41$ & 12.2 & $12 / 64$ & 18.8 & $10 / 49$ & 20.4 & $2 / 15$ & 13.3 & 0.43 & 0.4 & 1.0 & 0.72 \\
\hline B-Symptoms & $18 / 36$ & 50 & $29 / 60$ & 48.3 & $21 / 47$ & 44.7 & $8 / 13$ & 61.5 & 1.0 & 0.66 & 0.53 & 0.35 \\
\hline $\begin{array}{l}\text { Extranodal (EN) } \\
\text { status }\end{array}$ & & & & & & & & & $0.7^{\mathrm{c}}$ & $0.51^{\mathrm{c}}$ & $0.6^{\mathrm{c}}$ & $0.35^{\mathrm{c}}$ \\
\hline EN-sites 0 & $31 / 39$ & 79.5 & $46 / 62$ & 74.2 & $36 / 49$ & 73.5 & $10 / 13$ & 76.9 & 0.64 & 0.62 & 1.0 & 1.0 \\
\hline EN-sites 1 & $6 / 39$ & 15.4 & $10 / 62$ & 16.1 & $7 / 49$ & 14.3 & $3 / 13$ & 23.1 & 1.0 & 1.0 & 0.67 & 0.42 \\
\hline EN-sites $\geq 2$ & $2 / 39$ & 5.1 & $6 / 62$ & 9.7 & $6 / 49$ & 12.2 & $0 / 13$ & 0 & 0.48 & 0.29 & 1.0 & 0.33 \\
\hline Spleen involved & $1 / 39$ & 2.6 & $9 / 62$ & 14.5 & $7 / 49$ & 14.3 & $2 / 13$ & 15.4 & 0.08 & 0.07 & 0.15 & 1.0 \\
\hline $\begin{array}{l}\text { Mediastinum } \\
\text { involved }\end{array}$ & $29 / 39$ & 74.4 & $48 / 62$ & 77.4 & $36 / 49$ & 73.5 & $12 / 13$ & 92.3 & 0.81 & 1.0 & 0.25 & 0.26 \\
\hline Inguinal involved & $1 / 39$ & 2.6 & $3 / 62$ & 4.8 & $3 / 49$ & 6.1 & $0 / 13$ & 0 & 1.0 & 0.63 & 1.0 & 1.0 \\
\hline \multicolumn{13}{|l|}{$\begin{array}{l}\text { Laboratory } \\
\text { Parameters }\end{array}$} \\
\hline EBV-positive & $4 / 30$ & 13.3 & $9 / 46$ & 19.6 & $8 / 37$ & 21.6 & $1 / 9$ & 11.1 & 0.55 & 0.53 & 1.0 & 0.66 \\
\hline $\begin{array}{l}\text { Elevated LDH } \\
>250 \mathrm{U} / 1\end{array}$ & $9 / 37$ & 24.3 & $7 / 58$ & 12.1 & $5 / 45$ & 11.1 & $2 / 13$ & 15.4 & 0.16 & 0.15 & 0.7 & 0.65 \\
\hline $\begin{array}{l}\text { Leukocytosis } \\
\geq 15000 / \mu 1\end{array}$ & $11 / 38$ & 28.9 & $14 / 61$ & 23 & $11 / 48$ & 22.9 & $3 / 13$ & 23 & 0.64 & 0.62 & 1.0 & 1.0 \\
\hline $\begin{array}{l}\text { Hypoalbuminemia } \\
<4 \mathrm{~g} / \mathrm{dl}\end{array}$ & $11 / 29$ & 37.9 & $12 / 46$ & 26.1 & $6 / 34$ & 17.6 & $6 / 12$ & 50 & 0.31 & 0.09 & 0.51 & 0.05 \\
\hline $\mathrm{Hb} .<10.5 \mathrm{~g} / \mathrm{dl}$ & $5 / 38$ & 13.2 & $16 / 60$ & 26.7 & $12 / 47$ & 25.5 & $4 / 13$ & 30.8 & 0.14 & 0.18 & 0.21 & 0.73 \\
\hline $\mathrm{ESR}>50 \mathrm{~mm} / \mathrm{h}$ & $16 / 29$ & 55.2 & $23 / 41$ & 56.1 & $20 / 33$ & 60.6 & $3 / 8$ & 37.5 & 1.0 & 0.8 & 0.45 & 0.27 \\
\hline Therapy Protocol & & & & & & & & & $0.7^{c}$ & $0.8^{\mathrm{c}}$ & $0.2^{\mathrm{c}}$ & $0.15^{\mathrm{c}}$ \\
\hline ABVD & $14 / 39$ & 35.9 & $25 / 62$ & 40.3 & $21 / 49$ & 42.9 & $4 / 13$ & 30.8 & 0.68 & 0.52 & 1.0 & 0.53 \\
\hline BEACOPP & $19 / 39$ & 48.7 & $25 / 62$ & 40.3 & $21 / 49$ & 42.9 & $4 / 13$ & 30.8 & 0.42 & 0.67 & 0.34 & 0.54 \\
\hline Other & $6 / 39$ & 15.4 & $12 / 62$ & 19.4 & $7 / 49$ & 14.3 & $5 / 13$ & 38.5 & 0.79 & 1.0 & 0.12 & 0.11 \\
\hline Radiation (yes) & $27 / 38$ & 71.1 & $41 / 61$ & 67.2 & $32 / 49$ & 65.3 & $9 / 12$ & 75 & 0.82 & 0.65 & 1.0 & 0.73 \\
\hline
\end{tabular}

Abbreviations: EN, extranodal; EBV, Epstein-Barr Virus; ESR, erythrocyte sedimentation rate; LDH, lactate dehydrogenase $>250 \mu \mathrm{g} ; \mathrm{Hb}$, hemoglobin; N, number of cases per genotype-specific subgroup; No., number of patients; LN, lymph node; $P$ values from Fisher's exact test for comparison dichotomous variables (provided per line), chi-square for comparisons when taking all categories into account (provided in the same line as category-heading and indicated by ${ }^{\mathrm{c}}$ ), or student $t$-test for age (indicated by ${ }^{t}$ ). 

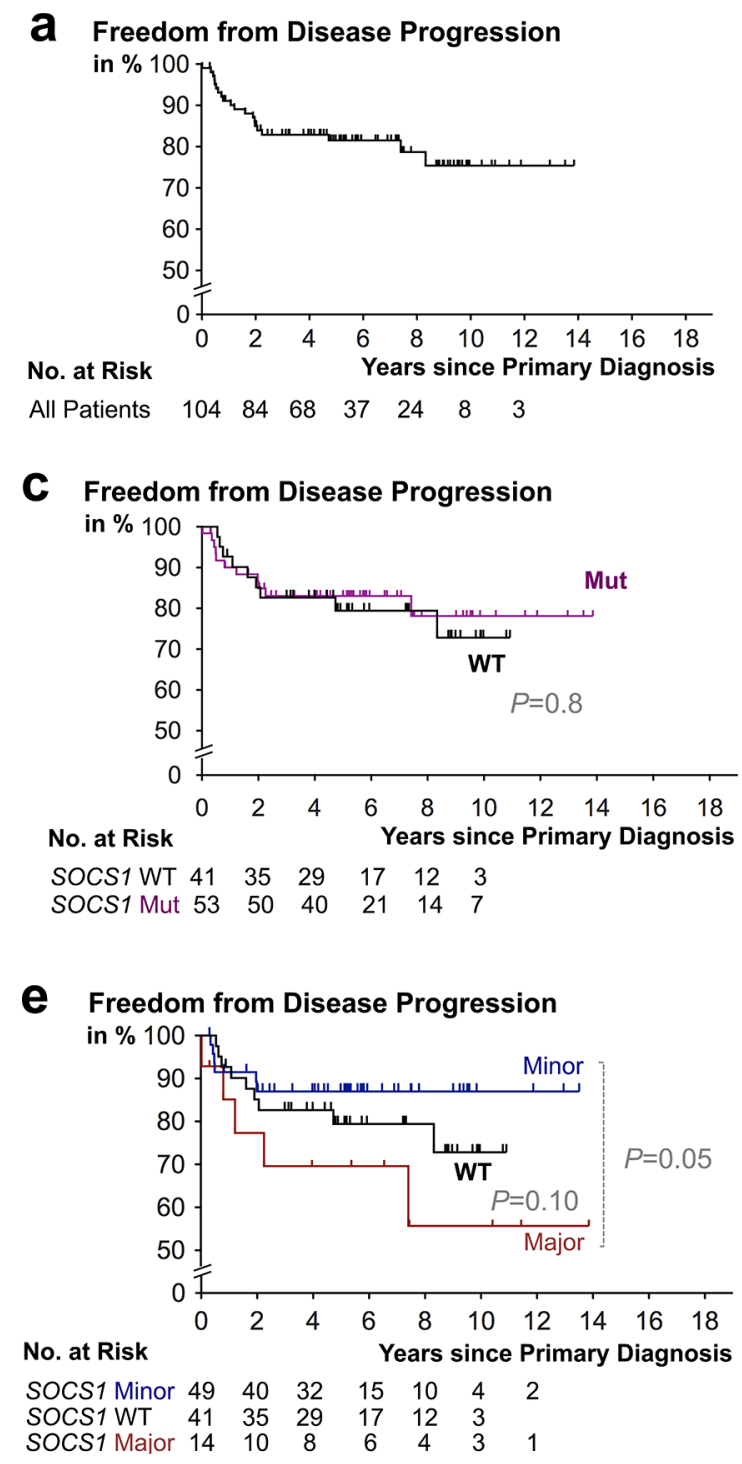
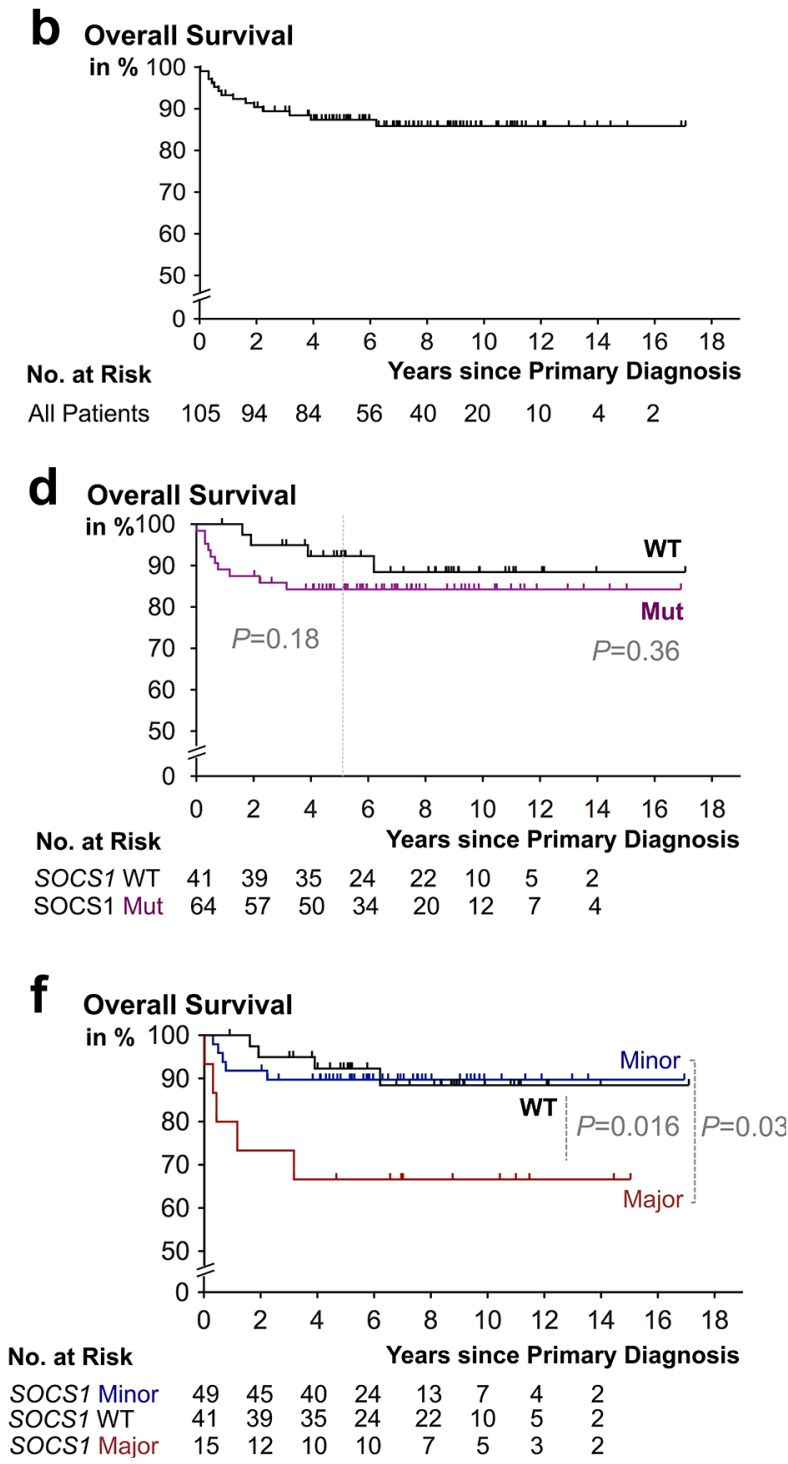

Figure 3: Kaplan-Meier survival estimates according to SOCS1 mutation status. Progression free a. and overall survival b. in our study cohort. c. Patients with classical Hodgkin lymphoma (cHL) containing HRS cells that harbor SOCS1 mutations (Mut) mutations (purple) had a no significantly different rate of freedom from disease progression when compared to patient whose HRScells harbored SOCS1 wild-type (black). d. cHL-patients with RS-cells that harbored SOCS1 mutations (purple) showed earlier events; however, had no significantly shorter overall survival times when compared to patient whose HRS-cells harbored SOCS1 wild-type (black). e. Patients with classical Hodgkin lymphoma (cHL) containing HRS cells that harbor SOCS1 major mutations (red) had a significantly different rate of freedom from disease progression $(P=0.05)$ when compared to cases with SOCS1 minor mutations (blue). d. cHL-patients with RS-cells that harbored SOCS1 major mutations (red) had significantly shorter overall survival times when compared to patient whose HRS-cells harbored SOCS1 wild-type (black) or SOCS1 minor mutations (blue; $P=0.03$ ). All $P$ values from $\log$ rank tests.

did not reach significance $(P=0.10$; Figure $4 a)$, OS was significantly shorter in the SOCS1 major subgroup $(P=0.016$ Figure $4 \mathrm{~b})$. Based on these univariate comparisons, we assessed independence of the SOCS1 major status in multivariate Cox models for FFDP and OS (Figure 4c, 4d). With respect to overall survival (Figure 4d), the SOCS1 major status had significant prognostic information independent of the covariates age, sex, AAS, and extranodal involvement $(P=0.005$; Figure $4 d)$. Together these data indicate that the SOCS1 gene mutation status had little prognostic impact by itself; however, the SOCS1 mutation subtype, and in particular the SOCS1 major mutations, has impact independent from the canonical prognostic biomarkers in cHL [14].

\section{DISCUSSION}

Here, we evaluated the frequency, clinical phenotype and prognostic value of SOCS1 mutations in HRS cells in a cohort of $105 \mathrm{cHL}$ patients. We report that HRS cells harbor SOCS1 mutations in over $60 \%$, which is one of the most frequently mutated genes in cHL. We describe that 
Freedom from Disease Progression

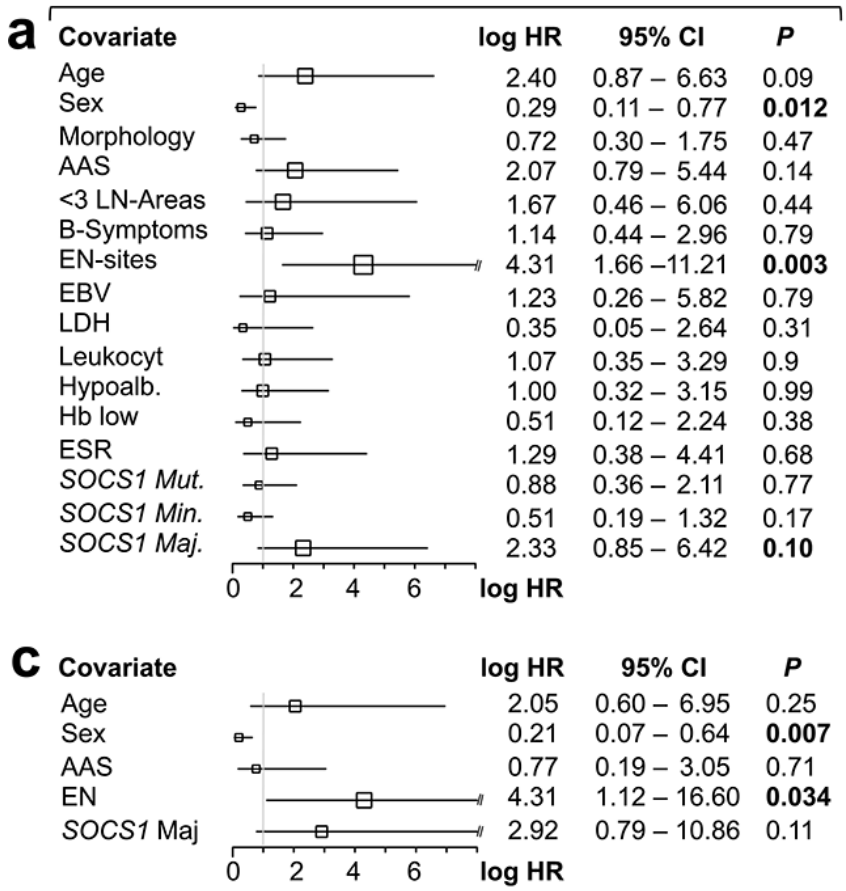

Overall Survival

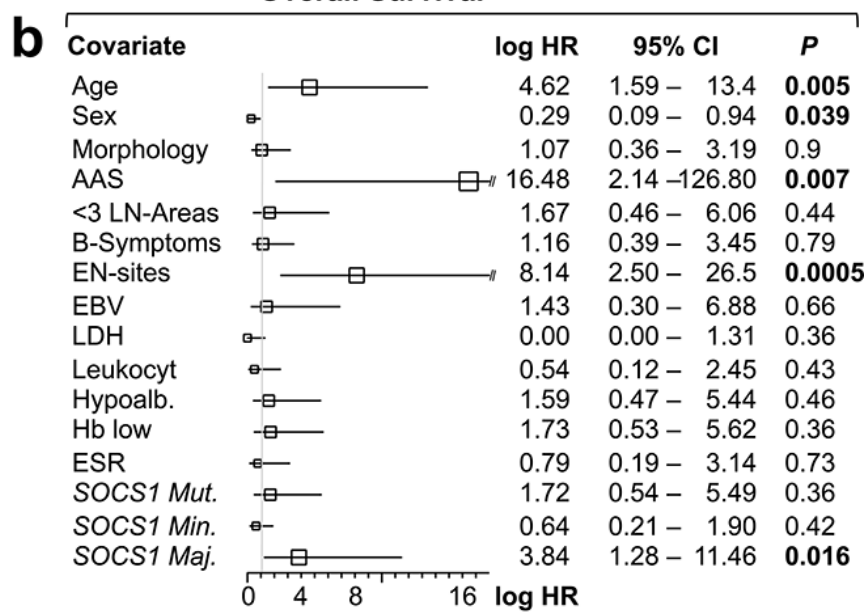

d Covariate
Age
Sex
AAS
EN
SOCS1 Maj

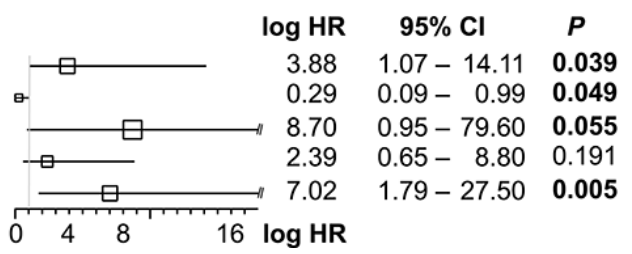

Figure 4: Forest plots of univariate $\mathbf{a}, \mathbf{b}$. and multivariate $\mathbf{c}, \mathbf{d}$. $\log$ hazard ratios (HR) for failure from tumor progression (a, c) and overall survival (b, d) according to epidemiological, clinico-pathological, serological covariates, and SOCS1 gene status as well as mutation types. a, b. Univariate and c, d. multivariate Cox proportional hazards regression models. Abbreviations: AAS, Ann Arbor Stage; < 3 LNAreas, number of independently involved lymph node regions; EN, extranodal; Leukocyt, leukocytosis; hypoalb, hypoalbuminemia; ESR, erythrocyte sedimentation rate. For specific cutoffs see methods or tables.

no particular clinical phenotype is associated with SOCS1 mutant cHL patients and found that the SOCS1 mutation type is a single-gene prognostic biomarker in a subset of cHL patients. While confirmation in an independent cohort -ideally by a separate group — is pending, our findings have several implications:

The key hurdle in genotyping of $\mathrm{cHL}$ is isolation of HRS cells or more specifically their nucleic acids. We concede that laser-capture microdissection of HRS cells is time consuming ( $\sim 15$ hours per case) and clearly does not qualify as routine diagnostics. Furthermore, the lack of mutational hotspots suggests that full-length sequencing of SOCS1 is necessary to determine the SOCS1 mutation status. The shortness of the SOCS1 coding region (636 bp) is encouraging; however, the very high GC-content $(>80 \%)$ has placed SOCS1 already on the list of genes with poor coverage and sequencing quality - even when using high-performance next-generation genotyping [34]. Nevertheless, our study provides a manually microdissected and Sangersequencing based starting-point as proof of general feasibility to perform SOSC1 genotyping in HRS cells. Methodological progress [35] will hopefully lead to detection of mutated genes in tumor tissue with low frequency of neoplastic cells. Furthermore, availability of early evidence for genotyping of cell-free DNA in patients may open up novel approaches for routine diagnostic assessment of the SOCS1 mutation status [36].
From a biology perspective, our finding that SOCS1 is a target of SHM in cHL has several implications. First, the key mutational features of genes affected by SHM (originally described in DLBCL [28] and subsequently verified in several lymphomas $[18,25,26])$ include: single nucleotide substitutions, occasional deletions and insertions, a preference for transitions over transversions, a preferential distribution within the RGYW motifs, and elevated ratios of $\mathrm{G} / \mathrm{C}$ over A/T substitutions. Our report confirms the presence of all these features in the SOCS1 gene in HRS cells of cHL and gives further support to the concept of aberrant SHM as a key oncogenic event in B cell neoplasia [28] although this occurs statistically less frequent than in DLBCL $[18,20]$.

With respect to the pathogenesis of $\mathrm{cHL}$, SOCS1 may play an interesting role in the acquisition of autonomous growth of HRS cells. Briefly, in normal B-cells, cytokine effects (e.g. IL-4) are transmitted via specific receptors (e.g. IL-4R) and their downstream signaling cascades (e.g. JAK/STAT) that collectively stimulate proliferation and clonal expansion $[37,38]$. As the name implies, the normal function of SOCS1 in this cascade is to inhibit the JAK/STAT signaling pathway. We have previously shown that SOCS1 mutations lead to sustained action of phosphoJAK2 and ultimately to constitutive activation of JAK/ STAT signaling $[21,24]$. Thus the acquisition of SOCS1 mutations may render the neoplastic cell independent from 
extrinsic signals and thereby acquire autonomous growth in $\mathrm{cHL}$. The frequency of $>60 \%$ of cases suggest that SOCS1 mutations probably are driver mutations in cHL. A recent study using flow-cytometry based RS-cell isolation in 10 cases and 2 cell lines delineated very similar SOCS1 mutation frequencies (66.6\%) [35]. Moreover, the group performed whole-exome sequencing, which allows a more comprehensive view of mutational events in cHL. The prior description of JAK2 amplification [39] and associated co-amplification of PD-L1 [40] sparked a review of the distribution of selected mutational events to each other (Supplementary Figure S2). Although at higher frequency $(66.6 \%)$, SOCS1 mutations occur in association with $J A K 2 / P D-L 1$ copy number gains (but not in association with other frequent mutations; e.g. B2M). While therapeutic implications of these associations remain to be determined $[9,41]$, the co-occurrence of SOCS1 mutations with JAK2 amplifications suggest a subset of cHL in 'JAK2-overdrive/hyperactivation' that may contribute to outcome differences (Figure 3).

From a clinical perspective, our key finding is that the prognosis of patients with SOCS1 mutations depends on the nature of the mutation. We organized mutations by the lengths of intact encoded sequence, thus splitting the cases in two groups: SOCS1 major, which has a poor prognosis and SOCS1 minor, which has a prognosis similar to the SOCS1 wild-type group. Despite being the largest SOCS1 mutation study in laser-capture microdissected HRS-cells from cHL samples to date, and the high prevalence of mutated cases, the number of cases with events (i.e. progress, disease-related death) in the mutated subgroups is relatively small. In diseases with high cure-rates this is a common problem-especially when dealing with highly resolved molecular stratification of patients. Nonetheless, SOCS1 as a prognostic biomarker is able to tease out the small number of patients with events $(P=0.045$ without FFPE samples; $P=0.03$ with FFPE samples). The estimated hazard ratios - in particular for the SOCS1 major subgroup - are so large that the survival difference maintained statistical significance in uni- and multivariate analyses (Figure 4). Finally, we are facing the different prognostic effects of SOCS1 major mutations in cHL (associated with shorter OS) and DLBCL (associated with longer OS) [20]. The clinical impact of SOCS1 minor and major mutations seem to profoundly differ depending on differences in treatment regimens and/or the cellular context, i.e., the malignant $\mathrm{B}$ cell in DLBCL with lots of B cell functions still intact and active vs. the HRS cell in cHL with its notorious loss of B cell identity.

In summary, we report that SOCS1 mutations occur in $>60 \%$ of $\mathrm{cHL}$ and that the mutation subtype predict divergent outcomes in at least a subset of patients. Thus, we propose the SOCS1 mutation status as a novel HRS cellderived, single gene biomarker with prognostic relevance.

\section{MATERIALS AND METHODS}

\section{Study population and inclusion criteria}

This study includes an institutional review boardapproved, retrospective archival search and analysis of a series of patients with biopsy-proven cHL seen at Ulm University Hospital/Comprehensive Cancer Center Ulm (CCCU) [42]. Inclusion criteria were: a) at least $0.5 \mathrm{~cm}^{3}$ fresh-frozen and cryobanked tissue where b) cHL was histological confirmed by at least two pathologists (JKL, PM) using WHO criteria [43], c) negativity for HIV, and d) treatment naïve. To increase statistical power for outcome observations we employed a previously chosen approach [27] and established SOCS1 genotyping on FFPE material (Supplementary Table S1, Supplementary Figure S1).

\section{Data collection and endpoints}

Medical records were reviewed to extract data on clinicopathologic features and outcomes by three of the authors (JKL, NR, AV). The primary end points in this study were overall survival (OS) and freedom from disease progression (FFDP). OS was defined as the timespan from date of diagnosis until date of death. FFDP was defined as the time-span from date of diagnosis until the date of a disease-related event, defined as progression during treatment, death during treatment (with unknown disease status), less than a complete remission after treatment and relapse after treatment, including death due to lymphoma progression after end of treatment. We censored patients at the date of last follow up when alive or lost to follow up.

\section{Laser-capture microdissection and extraction of nucleic acids}

To procure neoplastic HRS-cells or the surrounding non-neoplastic inflammatory infiltrate (referred to as 'infiltrate'), we performed laser-capture microdissection (LCM) using either a PALM MicroBeam IV or a PALM Robot MicroBeam system (both Carl Zeiss, Jena, Germany). We used $12 \mu \mathrm{m}$ thick cryosections mounted on traditional glass slides covered with transparent thermoplastic film. The target cells are identified in phase-contrast, hematoxylin counterstaining, or CD30immunohistochemistry, followed by capture into LCMcaps (adhesive cap 200 opaque; Zeiss, Jena, Germany). The laser settings for cutting were $43 \mathrm{~mW}$ with a focus of $85 \mu \mathrm{m}$ for $1-2 \mathrm{~ns}$ at 30 pulses per second, whereas procurement was performed using $70 \mathrm{~mW}$ with a focus of $80 \mu \mathrm{m}$ for $1-2 \mathrm{~ns}$ at 30 pulses per second. Typically, we procured $>50$ up to 1000 laser-capture microdissected cells per case. For extraction of DNA and RNA we employed the PicoPure DNA extraction kit and the Pico Pure RNA isolation kit (both Applied Biosystems, 
Darmstadt, Germany), respectively. Initial digestion volume was $25 \mu \mathrm{l}$ for DNA (25 $\mu$ l reconstitution buffer with Proteinase $\mathrm{K}+$ for $3 \mathrm{~h}$ at $56^{\circ} \mathrm{C}$ ) and $12 \mu$ for RNA (2 $\mu$ f for quality assessment using an Agilent 2100 Bioanalyzer and $10 \mu \mathrm{l}$ as template for downstream RTPCR). For RT-PCR, we employed a two-step procedure with a first RT-step using the Super Script II Reverse Transcriptase (Invitrogen, Karlsruhe, Germany) with poly-dT(15) primers (Biomers, Ulm, Germany).

\section{Nested PCR design and SOCS1 sequencing}

The SOCS1 gene is composed of two exons separated by one intron (length:550 bp): exon 1 (length:101 bp) contains the 5' UTR (untranslated region) and exon 2 (length:1124 bp) contains part of the 5' UTR (length:50 bp), the translation initiation site (ATG position 705), the stop codon (TGA position $1340=\mathrm{c} .636$ ), and the 3' UTR. The target used for nested PCR design was the complete open reading frame (length: $636 \mathrm{bp}$ ). The first reaction employed previously established (external) primers $[20,21]$ that capture a 761 bp PCR fragment: SOCS1-EX2-EXT-For (5'-CAC CCC CGG ACG CTA TG$\left.3^{\prime}\right)$ and SOCS1-EX2-EXT-Rev (5'-CCA CAT GGT TCC AGG CAA GTA-3'). Amplification reactions were done using a Taq DNA Polymerase PCR kit (Qiagen, Hilden, Germany) with a final volume of $50 \mu \mathrm{l}$ in a Primus96 plus thermocycler (MWG-Biotech, Ebersberg, Germany). To increase specific binding, nested PCR protocols employed a step-wise decreasing temperature program for annealing. Specifically, denaturation (at $95^{\circ} \mathrm{C}$ for $35 \mathrm{~s}$ ) and elongation (at $72^{\circ} \mathrm{C}$ for $1 \mathrm{~min}$ ) were kept constant, whereas annealing was performed twice at $62^{\circ} \mathrm{C}(35 \mathrm{~s})$, twice at $60^{\circ} \mathrm{C}$ and $58^{\circ} \mathrm{C}$ followed by 35 cycles at $56^{\circ} \mathrm{C}$. In the second reaction, the first PCR amplicon $(2 \mu \mathrm{l})$ served as a template for the nested amplification of a $698 \mathrm{bp}$ fragment using a pair of internal primers: SOCS1-EX2-INFor (5'-GGC TGG CCC CTT CTG TAG-3') and SOCS1EX2-IN-Rev (5'-ACG GCA TCC CAG TTA ATG CT-3'). PCR products were analyzed by electrophoresis in a $2 \%$ agarose gel, stained with ethidium bromide, visualized in ultraviolet transillumination and photographed using an Alpha Imager EP (Alpha Innotech/ProteinSimple, Santa Clara, CA, USA). For each PCR reaction, we included a positive wild-type control [21] to verify amplification of SOCS1 and a negative control containing Milli-Q water.

\section{SOCS1 sequence and mutation analysis}

For sequencing, the amplified products were processed by agarose gel purification using the peqGOLD Gel Extraction Kit (peqlab, Erlangen, Germany). Sanger DNA sequencing employed the BigDye Terminator v3.1 Kit on a 3130 Genetic Analyzer (both ABI, Carlsbad, CA). Dye signals were translated by the $K B^{\mathrm{TM}}$ Base Caller Software and visualized using the Sequencing Analysis Software v5.4 (both ABI), ChromasPro
Software (Technelysium, South Brisbane, Australia) or MacSequenceView (http://www.gotoes.org). Forward and reverse sequences were manually analyzed by blasting the obtained sequence against the human SOCS1 sequence (ENST0000332029; SOCS1-001; http://www.ensembl. org). After annotation of the nucleotide alterations, sequence information was translated into protein sequence (http://www.expasy.org/translate) and alterations were mapped over the open reading frame as well as the known SOCS1 protein domains. Additionally, the DNA sequence of mutated SOCS1 cases was used to analyze the targeting of the somatic hypermutation mechanism at specific hotspot motifs [28]. We used a DNA pattern search tool to identify somatic hypermutation hotspots (http://www.geneinfinity.org/sms/sms_DNApatterns) and for determination of the mutation distribution over the genetic locus, we employed previously established approaches [28]. Specifically, these preferred hotspots include $\mathrm{RGYW} / \mathrm{WRCY}$ (G:C is the mutable position; $\mathrm{R}=$ purine, $\mathrm{Y}=$ pyrimidine, and $\mathrm{W}=\mathrm{A} / \mathrm{T}$ ) [30], $\mathrm{DGYW} /$ WRCH ( $\mathrm{G}$ : $\mathrm{C}$ is the mutable position; $\mathrm{D}=\mathrm{G} / \mathrm{T} / \mathrm{A} ; \mathrm{H}=$ $\mathrm{T} / \mathrm{C} / \mathrm{A}$ ) [31] and WA/TW (A:T is the mutable position) nucleotide pattern at both DNA strands [29]. For in silico prediction of functional consequences of amino acid substitutions we employed the two separate prediction tools SIFT (http://sift.jcvi.org/) and PolyPhen-2 (http:// genetics.bwh. harvard.edu/pph2).

\section{Statistical analysis}

Statistical analysis consisted of Fisher's exact test (association of genotype with dichotomous factors), chisquare, or student's $t$-test (comparison of means). We calculated progression-free survival from the date of first diagnosis until date of objective disease progression or death from any cause. The Kaplan-Meier method was used to estimate FFDP and OS times. We used uni- as well as multivariate Cox proportional hazards regression models to analyze survival data. Given survival times, final life status (alive or dead) and one (univariate) or more (multivariate) covariates, the regression models produce a baseline survival curve and covariate coefficient estimates with their standard errors, 95\% confidence intervals, and significance levels. The covariates included in these analyses were (parenthesis provide values set to 1): age ( $\geq 45$ ), sex (female), morphology (nodular sclerosing), AAS (III/IV), lymph node involvement ( $\geq 3$ sites), extranodal involvement ( $\geq 1$ site), EBV (positive), LDH $(>250 \mathrm{U} / 1)$, leukocytosis $(\geq 15000 / \mu \mathrm{l})$, hypoalbuminemia $(<4 \mathrm{~g} / \mathrm{dl})$, low hemoglobin $(<10.5 \mathrm{~g} / \mathrm{dl})$, increased erythrocyte sedimentation rate $(>50 \mathrm{~mm} / \mathrm{h})$, SOCS1 status (mutation positive); SOCS1 major and SOCS1 minor. In univariate analyses, we examined covariates for their previously acknowledged prognostic impact, when applicable. In a second step, we combined factors demonstrating significance in univariate assessment in a multivariate analysis. We employed the same covariates in 
multivariate models to allow comparison between FFDP and OS. For composition of the heatmap (Supplementary Figure S2) that illustrates the relationship of SOCS1 and $B 2 M$ mutations, as well as $J A K 2$ and $P D-L 1$ amplifications, we performed an in silico analysis of a recent next-generation whole-exome sequencing study [35]. We employed the $\mathrm{R}$ package (http://www.r-project.org) and GraphPad Prism for data mining; in all statistical analyses we defined $P<0.05$ as significant.

\section{ACKNOWLEDGMENTS}

We thank Julia Melzner, Iwona Nerbas, Ulrike Kostezka PhD, Elena Kelsch, Elena Moser, and Karola Dorsch for skillful technical assistance. Finally, we thank Prof. Dr. T.F.E. Barth for valuable discussions.

\section{FUNDING}

The Development of Interdisciplinary Oncology Centers of Excellence Program of the Deutsche Krebshilfe supported the Comprehensive Cancer Center Ulm (CCCU; Grant number: 108649). The Else-Kröner Fresenius Foundation supported this study with research funding to JKL. The PhD program Experimental Medicine at Ulm University supported KH.

\section{CONFLICTS OF INTEREST}

All authors declare no potential conflict of interest or competing financial interests

\section{Author contributions}

Conception, idea, and design: PM; case selection: JKL, AV, PM; experiments, genotyping and mutational analysis: JKL, KH, AMB, DL; assembly of clinical- and follow-up data: JKL, KH, AMB, CW, NR, AV, PM; the initial manuscript was written by JKL, revised by AV, PM and all authors approved the submitted version.

\section{REFERENCES}

1. Canellos GP, Rosenberg SA, Friedberg JW, Lister TA, Devita VT. Treatment of Hodgkin lymphoma: a 50-year perspective. J Clin Oncol. 2014; 32:163-168.

2. Behringer K, Goergen H, Hitz F, Zijlstra JM, Greil R, Markova J, Sasse S, Fuchs M, Topp MS, Soekler M, Mathas S, Meissner J, Wilhelm M, et al. Omission of dacarbazine or bleomycin, or both, from the ABVD regimen in treatment of early-stage favourable Hodgkin's lymphoma (GHSG HD13): an open-label, randomised, non-inferiority trial. Lancet. 2014.
3. von Tresckow B, Plutschow A, Fuchs M, Klimm B, Markova J, Lohri A, Kral Z, Greil R, Topp MS, Meissner J, Zijlstra JM, Soekler M, Stein H, et al. Dose-intensification in early unfavorable Hodgkin's lymphoma: final analysis of the German Hodgkin Study Group HD14 trial. J Clin Oncol. 2014; 30:907-913.

4. Engert A, Haverkamp H, Kobe C, Markova J, Renner C, Ho A, Zijlstra J, Kral Z, Fuchs M, Hallek M, Kanz L, Dohner H, Dorken B, et al. Reduced-intensity chemotherapy and PET-guided radiotherapy in patients with advanced stage Hodgkin's lymphoma (HD15 trial): a randomised, open-label, phase 3 non-inferiority trial. Lancet. 2012; 379:1791-1799.

5. Wongso D, Fuchs M, Plutschow A, Klimm B, Sasse S, Hertenstein B, Maschmeyer G, Vieler T, Duhrsen U, Lindemann W, Aulitzky W, Diehl V, Borchmann P, et al. Treatment-related mortality in patients with advanced-stage hodgkin lymphoma: an analysis of the german hodgkin study group. J Clin Oncol. 2013; 31:2819-2824.

6. Halbsguth TV, Boll B, Borchmann P, Diehl V. The unique characteristics and management of patients over 60 years of age with classic Hodgkin lymphoma. Curr Hematol Malig Rep. 2012; 6:164-171.

7. Morschhauser F, Brice P, Ferme C, Divine M, Salles G, Bouabdallah R, Sebban C, Voillat L, Casasnovas O, Stamatoullas A, Bouabdallah K, Andre M, Jais JP, et al. Risk-adapted salvage treatment with single or tandem autologous stem-cell transplantation for first relapse/refractory Hodgkin's lymphoma: results of the prospective multicenter H96 trial by the GELA/SFGM study group. J Clin Oncol. 2008; 26:5980-5987.

8. Younes A, Gopal AK, Smith SE, Ansell SM, Rosenblatt JD, Savage KJ, Ramchandren R, Bartlett NL, Cheson BD, de Vos S, Forero-Torres A, Moskowitz CH, Connors JM, et al. Results of a pivotal phase II study of brentuximab vedotin for patients with relapsed or refractory Hodgkin's lymphoma. J Clin Oncol. 2012; 30:2183-2189.

9. Ansell SM, Lesokhin AM, Borrello I, Halwani A, Scott EC, Gutierrez M, Schuster SJ, Millenson MM, Cattry D, Freeman GJ, Rodig SJ, Chapuy B, Ligon AH, et al. PD-1 blockade with nivolumab in relapsed or refractory Hodgkin's lymphoma. N Engl J Med. 2015; 372:311-319.

10. Donaldson SS, Hancock SL. Second cancers after Hodgkin's disease in childhood. N Engl J Med. 1996; 334:792-794.

11. Schellong G, Riepenhausen M, Bruch C, Kotthoff S, Vogt J, Bolling T, Dieckmann K, Potter R, Heinecke A, Bramswig J, Dorffel W. Late valvular and other cardiac diseases after different doses of mediastinal radiotherapy for Hodgkin disease in children and adolescents: report from the longitudinal GPOH follow-up project of the GermanAustrian DAL-HD studies. Pediatr Blood Cancer. 2010; 55:1145-1152.

12. Behringer K, Mueller H, Goergen $H$, Thielen I, Eibl AD, Stumpf V, Wessels C, Wiehlputz M, Rosenbrock J, 
Halbsguth T, Reiners KS, Schober T, Renno JH, et al. Gonadal function and fertility in survivors after Hodgkin lymphoma treatment within the German Hodgkin Study Group HD13 to HD15 trials. J Clin Oncol. 2013; 31:231-239.

13. Hasenclever D. The disappearance of prognostic factors in Hodgkin's disease. Ann Oncol. 2002; 1:75-78.

14. Hasenclever D, Diehl V. A prognostic score for advanced Hodgkin's disease. International Prognostic Factors Project on Advanced Hodgkin's Disease. N Engl J Med. 1998; 339:1506-1514.

15. Kuppers R. The biology of Hodgkin's lymphoma. Nat Rev Cancer. 2009; 9:15-27.

16. Steidl C, Farinha P, Gascoyne RD. Macrophages predict treatment outcome in Hodgkin's lymphoma. Haematologica. 2011; 96:186-189.

17. Canioni D, Deau-Fischer B, Taupin P, Ribrag V, Delarue R, Bosq J, Rubio MT, Roux D, Vasiliu V, Varet B, Brousse N, Hermine O. Prognostic significance of new immunohistochemical markers in refractory classical Hodgkin lymphoma: a study of 59 cases. PLoS One. 2009; 4:e6341.

18. Mottok A, Renne C, Seifert M, Oppermann E, Bechstein W, Hansmann ML, Kuppers R, Brauninger A. Inactivating SOCS1 mutations are caused by aberrant somatic hypermutation and restricted to a subset of B-cell lymphoma entities. Blood. 2009; 114:4503-4506.

19. Barth TF, Leithauser F, Joos S, Bentz M, Moller P. Mediastinal (thymic) large B-cell lymphoma: where do we stand? Lancet Oncol. 2002; 3:229-234.

20. Schif B, Lennerz JK, Kohler CW, Bentink S, Kreuz M, Melzner I, Ritz O, Trumper L, Loeffler M, Spang R, Moller P. SOCS1 mutation subtypes predict divergent outcomes in diffuse large B-Cell lymphoma (DLBCL) patients. Oncotarget. 2013; 4:35-47.

21. Weniger MA, Melzner I, Menz CK, Wegener S, Bucur AJ, Dorsch K, Mattfeldt T, Barth TF, Moller P. Mutations of the tumor suppressor gene SOCS-1 in classical Hodgkin lymphoma are frequent and associated with nuclear phospho-STAT5 accumulation. Oncogene. 2006; 25:2679-2684.

22. Zhang J, Li H, Yu JP, Wang SE, Ren XB. Role of SOCS1 in tumor progression and therapeutic application. Int $\mathrm{J}$ Cancer. 2011; 130:1971-1980.

23. Zhang JG, Farley A, Nicholson SE, Willson TA, Zugaro LM, Simpson RJ, Moritz RL, Cary D, Richardson R, Hausmann G, Kile BJ, Kent SB, Alexander WS, et al. The conserved SOCS box motif in suppressors of cytokine signaling binds to elongins $\mathrm{B}$ and $\mathrm{C}$ and may couple bound proteins to proteasomal degradation. Proc Natl Acad Sci U S A. 1999; 96:2071-2076.

24. Melzner I, Bucur AJ, Bruderlein S, Dorsch K, Hasel C, Barth TF, Leithauser F, Moller P. Biallelic mutation of SOCS-1 impairs JAK2 degradation and sustains phosphoJAK2 action in the MedB-1 mediastinal lymphoma line. Blood. 2005; 105:2535-2542.
25. Khodabakhshi AH, Morin RD, Fejes AP, Mungall AJ, Mungall KL, Bolger-Munro M, Johnson NA, Connors JM, Gascoyne RD, Marra MA, Birol I, Jones SJ. Recurrent targets of aberrant somatic hypermutation in lymphoma. Oncotarget. 2012; 3:1308-1319.

26. Mottok A, Renne C, Willenbrock K, Hansmann ML, Brauninger A. Somatic hypermutation of SOCS1 in lymphocyte-predominant Hodgkin lymphoma is accompanied by high JAK2 expression and activation of STAT6. Blood. 2007; 110:3387-3390.

27. Steidl C, Lee T, Shah SP, Farinha P, Han G, Nayar T, Delaney A, Jones SJ, Iqbal J, Weisenburger DD, Bast MA, Rosenwald A, Muller-Hermelink HK, et al. Tumor-associated macrophages and survival in classic Hodgkin's lymphoma. N Engl J Med. 2010; 362:875-885.

28. Pasqualucci L, Neumeister P, Goossens T, Nanjangud G, Chaganti RS, Kuppers R, Dalla-Favera R. Hypermutation of multiple proto-oncogenes in B-cell diffuse large-cell lymphomas. Nature. 2001; 412:341-346.

29. Rogozin IB, Pavlov YI, Bebenek K, Matsuda T, Kunkel TA. Somatic mutation hotspots correlate with DNA polymerase eta error spectrum. Nat Immunol. 2001; 2:530-536.

30. Rogozin IB, Kolchanov NA. Somatic hypermutagenesis in immunoglobulin genes. II. Influence of neighbouring base sequences on mutagenesis. Biochim Biophys Acta. 1992; 1171:11-18.

31. Rogozin IB, Diaz M. Cutting edge: DGYW/WRCH is a better predictor of mutability at G:C bases in Ig hypermutation than the widely accepted RGYW/WRCY motif and probably reflects a two-step activation-induced cytidine deaminase-triggered process. J Immunol. 2004; 172:3382-3384.

32. Viviani S, Zinzani PL, Rambaldi A, Brusamolino E, Levis A, Bonfante V, Vitolo U, Pulsoni A, Liberati AM, Specchia G, Valagussa P, Rossi A, Zaja F, et al. ABVD versus BEACOPP for Hodgkin's lymphoma when highdose salvage is planned. N Engl J Med. 2011; 365:203-212.

33. Nogova L, Reineke T, Brillant C, Sieniawski M, Rudiger T, Josting A, Bredenfeld H, Skripnitchenko R, Muller RP, Muller-Hermelink HK, Diehl V, Engert A. Lymphocyte-predominant and classical Hodgkin's lymphoma: a comprehensive analysis from the German Hodgkin Study Group. J Clin Oncol. 2008; 26:434-439.

34. Zhang J, Grubor V, Love CL, Banerjee A, Richards KL, Mieczkowski PA, Dunphy C, Choi W, Au WY, Srivastava G, Lugar PL, Rizzieri DA, Lagoo AS, et al. Genetic heterogeneity of diffuse large B-cell lymphoma. Proc Natl Acad Sci U S A. 2013; 110:1398-1403.

35. Reichel J, Chadburn A, Rubinstein PG, Giulino-Roth L, Tam W, Liu Y, Gaiolla R, Eng K, Brody J, Inghirami G, Carlo-Stella C, Santoro A, Rahal D, et al. Flow sorting and exome sequencing reveal the oncogenome of primary Hodgkin and Reed-Sternberg cells. Blood. 2015; 125:1061-1072. 
36. Vandenberghe P, Wlodarska I, Tousseyn T, Dehaspe L, Dietrickx D, Verheecke M, Uyttebroeck A, Bechter O, Delforge M, Veandecaveye V, Brison N, Verhoef GEG, Legius E, et al. Non-invasive detection of genomic imbalances in Hodgkin/Reed-Sternberg cells in early and advanced stage Hodgkin's lymphoma by sequencing of circulating cell-free DNA: a technical proof-of-principle study. The Lancet Hematology. 2015; 2:e55-e65.

37. Natoli A, Lupertz R, Merz C, Muller WW, Kohler R, Krammer PH, Li-Weber M. Targeting the IL-4/IL-13 signaling pathway sensitizes Hodgkin lymphoma cells to chemotherapeutic drugs. Int J Cancer. 2013; 133:1945-1954.

38. Kis LL, Gerasimcik N, Salamon D, Persson EK, Nagy N, Klein G, Severinson E, Klein E. STAT6 signaling pathway activated by the cytokines IL-4 and IL-13 induces expression of the Epstein-Barr virus-encoded protein LMP-1 in absence of EBNA-2: implications for the type II EBV latent gene expression in Hodgkin lymphoma. Blood. 2010; 117:165-174.

39. Joos S, Kupper M, Ohl S, von Bonin F, Mechtersheimer G, Bentz M, Marynen P, Moller P, Pfreundschuh M, Trumper L, Lichter P. Genomic imbalances including amplification of the tyrosine kinase gene JAK2 in CD30+ Hodgkin cells. Cancer Res. 2000; 60:549-552.
40. Green MR, Monti S, Rodig SJ, Juszczynski P, Currie T, O'Donnell E, Chapuy B, Takeyama K, Neuberg D, Golub TR, Kutok JL, Shipp MA. Integrative analysis reveals selective 9p24.1 amplification, increased PD-1 ligand expression, and further induction via JAK2 in nodular sclerosing Hodgkin lymphoma and primary mediastinal large B-cell lymphoma. Blood. 2010; 116: 3268-3277.

41. Ahmed CM, Larkin J 3rd, Johnson HM. SOCS1 Mimetics and Antagonists: A Complementary Approach to Positive and Negative Regulation of Immune Function. Front Immunol. 2015; 6:183.

42. Xu C, Plattel W, van den Berg A, Ruther N, Huang X, Wang M, de Jong D, Vos H, van Imhoff G, Viardot A, Moller P, Poppema S, Diepstra A, et al. Expression of the c-Met oncogene by tumor cells predicts a favorable outcome in classical Hodgkin's lymphoma. Haematologica. 2012; 97:572-578.

43. Campo E, Swerdlow SH, Harris NL, Pileri S, Stein H, Jaffe ES. The 2008 WHO classification of lymphoid neoplasms and beyond: evolving concepts and practical applications. Blood. 2011; 117:5019-5032. 